\title{
Practices on Financial Literacy of Teachers in the Schools Division Office of Cabanatuan City
}

\author{
Kathleen Joy C. Abaya, Realethlyn A. Aguinaldo, Alyssa Bea B. Asprec, Jayson A. \\ Baylon, Joana S. Donato, Vivien Amor Viloria
}

Master in Business Administration, Graduate School, Nueva Ecija University of Science and Technology, Philippines

Received: 06 Jul 2021; Received in revised form: 14 Jul 2021; Accepted: 26 Jul 2021; Available online: 06 Aug 2021 (C)2021 The Author(s). Published by Infogain Publication. This is an open access article under the CC BY license (https://creativecommons.org/licenses/by/4.0/).

\begin{abstract}
This research looked at the financial literacy practices of teachers at Cabanatuan City's Schools Division Office in Nueva Ecija, Philippines. The research is descriptive in nature. A survey questionnaire was employed to collect data, and convenience sampling was used to select the 100 teachers who responded. Frequency count, percentage, and weighted mean were used to treat and analyze the data. The study revealed that teachers were aware of the necessity of saving money, whether for short- or longterm goals, and they invested in life insurance. They've been exercising the necessity of keeping track of their costs with a monthly household budget. They borrowed or loaned money not because they wanted to, but because of unexpected or unforeseen occurrences in their lives, such as personal or family emergencies, natural disasters, economic downturns, and other unexpected circumstances that necessitate financial needs.
\end{abstract}

Keywords - Expenses, financial literacy, loan decisions, savings, teachers.

\section{INTRODUCTION}

Financial literacy, also known as financial capacity, is the ability to efficiently manage one's financial resources for long-term financial security [1]. "Financial literacy is made up of two parts: comprehension and application" [2]. Financial literacy refers to a person's knowledge of personal finance and the use of that knowledge in managing one's finances. Countries all across the world have expressed worry about their citizens' lack of financial literacy. Low financial literacy has a significant cost for the general public, which has been clearly highlighted by several researchers around the world [3]. Major concerns such as poor retirement planning and a lack of savings can be ascribed to the citizenry's insufficient or lack of awareness in financial matters. "Young people, lowincome families, single parents, and persons with poor educational levels are the most vulnerable to debt" [4]. "Personal finance education was not taught in schools, and the terms "financial literacy" and "personal financial management" are now commonly used interchangeably"
[4]. Many Filipinos are financially illiterate and lack a clear understanding of basic financial principles. The general public's attitude toward spending and saving is also concerning [5]. It is not so much a dearth of information as it is a lack of skill to comprehend it. Many people appear to be unaware of the future financial load they will face as a result of borrowing at exorbitant interest rates. It's difficult to estimate how many people are making poor decisions without knowing all of the details of each situation. Young individuals frequently find themselves in debt, whether through loans or credit cards, and this early involvement can impede their capacity to build wealth [6]. A person may borrow money from a government or commercial lending agency for a variety of reasons. Various factors, such as family, education, hospitalization, and other personal unanticipated needs, have resulted in large borrowing. Unfortunately, obtaining loans from nonaccredited lenders with minimum standards is convenient. Filipinos are more likely to be victims of loan sharks and financial scams as a result of their high rate of informal borrowing [7].The bad financial status of individuals, who 
are drowning in large debt without a budget plan and making poor financial decisions, demonstrates the necessity for financial education [8]. In today's environment, the capacity to handle personal finances has become increasingly vital. Financial well-being is linked to a person's overall happiness with his or her financial situation [9]. "People must be clear about their goals and be prepared to make long-term investments for their children's education and retirement". They must also make short-term savings decisions, whether for a vacation, a down payment on a house, a car, or even to start a business. Consumers that are financially educated or have a superior understanding of money can make better decisions and accumulate more wealth [10].It's alarming to learn that public school teachers, who are treated as second-class citizens among government employees, are burdened by massive debts. Teachers, as members of a better-educated portion of the Filipino community, are thought to be particularly prone to large loans [11]. Professional and pre-service teachers in the country have very low financial literacy [12]. The purpose of this study is to determine the level of financial literacy among public-school teachers in order to better understand how financial ideas can be used to influence and assist teachers in making sound personal financial decisions. The study's evidence-based conclusions will serve as a foundation for making recommendations to address the need for proper financial education among public school teachers.

The aim of this research is to find out the practices on the financial literacy of teachers under the Schools Division Office of Cabanatuan City and to help them in managing their finances through measuring their awareness in terms of savings, expenses, and investments. It also identified the major reasons that affect the loan decisions of teachers in terms of their needs and wants and further propose necessary activities that will support their personal financial decisions towards their better lives.

\section{RESEARCH METHODOLOGY}

The study used a descriptive method of research since its focus was on determining the impact of financial literacy on the loan decisions of teachers under the Schools Division Office of Cabanatuan City. Descriptive research is devoted to the gathering of information about prevailing conditions or situations for the purpose of description and interpretation [13]. The main instrument utilized wasa questionnaire with prior approval from the Schools Division Office of Cabanatuan City before the conducting of the survey. Convenience sampling is used and available teachers who can respond to the survey became the respondents of the study. In total, 100 public school teachers were identified as the respondents of this study. For the data treatment and analysis, frequency count, percentages, and weighted mean were utilized.

\section{RESULTS AND DISCUSSION}

1. Impact of financial literacy on the loan decisions of teachers through measuring their awareness

\subsection{Savings}

Table 1. Savings

\begin{tabular}{|cl|c|c|}
\hline \multicolumn{1}{|c|}{ Item } & WM & VI \\
\hline $\begin{array}{l}\text { 1. } \\
\text { Income - Savings }= \\
\text { Expenses }\end{array}$ & 3.5 & $\begin{array}{c}\text { With good } \\
\text { knowledge }\end{array}$ \\
\hline 2. & should go to savings. & 3.22 & $\begin{array}{c}\text { With moderate } \\
\text { knowledge }\end{array}$ \\
\hline 3. & $\begin{array}{l}\text { Savings provide for your } \\
\text { short-term goals (less } \\
\text { than a year). }\end{array}$ & 2.94 & $\begin{array}{c}\text { With moderate } \\
\text { knowledge }\end{array}$ \\
\hline $\begin{array}{l}\text { 4. } \\
\text { Saving for your } \\
\text { emergency fund should } \\
\text { be equivalent to 3-6 } \\
\text { months' worth of your } \\
\text { living expenses. }\end{array}$ & 3.03 & $\begin{array}{c}\text { With moderate } \\
\text { knowledge }\end{array}$ \\
\hline $\begin{array}{l}\text { 5. } \\
\text { Saving money is an } \\
\text { expense. }\end{array}$ & 2.67 & $\begin{array}{c}\text { With moderate } \\
\text { knowledge }\end{array}$ \\
\hline General Weighted Mean & 3.072 & $\begin{array}{c}\text { With moderate } \\
\text { knowledge }\end{array}$ \\
\hline
\end{tabular}

Table 1 shows the responses of teachers with regards to their financial literacy awareness in terms of savings, "Income - Savings = Expenses" got the highest weighted mean of 3.5 with a verbal interpretation of "With good knowledge" and "Saving money is an expense" got the lowest weighted mean of 2.67 with a verbal interpretation of "With moderate knowledge". This indicates that teachers had been aware of the importance of saving money whether for their short-term or long-term goals. On Financial Planning Thumb Rules, "The very first rule of personal finance says: "Pay yourself first". It simply means that out of the monthly income, a certain percentage has to be saved before it is spent. 'Income minus savings equal to expenses' should be the rule and not vice-versa" [14]. Teachers already had the ideas and have been practicing some financial planning through developing the discipline to save first before spending. They were familiar and still eager to know the different terms, ideas and concepts to learn about savings.

\subsection{Expenses}


Table 2. Expenses

\begin{tabular}{|c|c|c|}
\hline Item & $\mathbf{W M}$ & VI \\
\hline $\begin{array}{l}\text { 1. You should be using } \\
\text { only } 70 \% \text { of your } \\
\text { income on all monthly } \\
\text { essential expenses. }\end{array}$ & 3.19 & $\begin{array}{l}\text { With moderate } \\
\text { Knowledge }\end{array}$ \\
\hline $\begin{array}{l}\text { 2. Making a monthly } \\
\text { household budget is the } \\
\text { best way to guarantee } \\
\text { that all bills are paid. }\end{array}$ & 3.59 & $\begin{array}{l}\text { With Good } \\
\text { Knowledge }\end{array}$ \\
\hline $\begin{array}{l}\text { 3. To live within your } \\
\text { means is making small } \\
\text { adjustments by } \\
\text { distinguishing between } \\
\text { the things you need and } \\
\text { the things you want }\end{array}$ & 3.45 & $\begin{array}{l}\text { With Good } \\
\text { Knowledge }\end{array}$ \\
\hline 4. $50 \%$ sale means to buy. & 2.87 & $\begin{array}{l}\text { With moderate } \\
\text { Knowledge }\end{array}$ \\
\hline $\begin{array}{l}\text { 5. Credit cards are toxic to } \\
\text { wealth-building. }\end{array}$ & 3.13 & $\begin{array}{l}\text { With moderate } \\
\text { Knowledge }\end{array}$ \\
\hline General Weighted Mean & 3.246 & $\begin{array}{c}\text { With moderate } \\
\text { Knowledge }\end{array}$ \\
\hline
\end{tabular}

The table shows the responses of respondents about their financial literacy awareness in terms of expenses. "Making a monthly household budget is the best way to guarantee that all bills are paid" got the highest weighted mean of 3.59 with a verbal interpretation of "With Good Knowledge" and " $50 \%$ sale means buy" got the lowest weighted mean of 2.87 with a verbal interpretation of "With Moderate knowledge".This indicates that teachers had been practicing the importance of having a monthly household budget in keeping track of their expenses. A monthly household budget aids in the allocation of funds for paying bills and expenditure control. Budgeting not only helps you track where your money goes, but also helps you uncover spending patterns [15].

\subsection{Investments}

Table 3. Investments

\begin{tabular}{|l|l|l|}
\hline \multicolumn{1}{|c|}{ Item } & WM & \multicolumn{1}{|c|}{ VI } \\
\hline $\begin{array}{l}\text { 1. Life Insurance provides } \\
\text { savings, investment, and } \\
\text { retirement income and it is } \\
\text { bought not because people have } \\
\text { to die, but because people have } \\
\text { to go on living. }\end{array}$ & 3.47 & $\begin{array}{l}\text { With } \\
\text { moderate } \\
\text { knowledge }\end{array}$ \\
\hline $\begin{array}{l}\text { 2. Compounding and consistent } \\
\text { investing will help you through }\end{array}$ & 3.27 & $\begin{array}{l}\text { With } \\
\text { moderate }\end{array}$ \\
\hline
\end{tabular}

IJELS-2021, 6(4), (ISSN: 2456-7620)

\begin{tabular}{|l|l|l|}
\hline $\begin{array}{l}\text { wealth-building. (Time } \\
\text { Deposits, Stocks, UITF, Mutual } \\
\text { Funds) }\end{array}$ & knowledge \\
\hline $\begin{array}{l}\text { 3. Developing healthy money } \\
\text { spending habits will help you } \\
\text { reach your financial freedom. }\end{array}$ & 3.41 & $\begin{array}{l}\text { With } \\
\text { moderate } \\
\text { knowledge }\end{array}$ \\
\hline $\begin{array}{l}\text { 4. Investments are passive } \\
\text { income. }\end{array}$ & 3.23 & $\begin{array}{l}\text { With } \\
\text { moderate } \\
\text { knowledge }\end{array}$ \\
\hline $\begin{array}{l}\text { 5. Investment will protect you } \\
\text { from inflation. }\end{array}$ & 3.24 & $\begin{array}{l}\text { With } \\
\text { moderate } \\
\text { knowledge }\end{array}$ \\
\hline General Weighted Mean & 3.324 & $\begin{array}{l}\text { With } \\
\text { moderate } \\
\text { knowledge }\end{array}$ \\
\hline
\end{tabular}

Table 3 shows the responses of the respondents regarding their financial literacy awareness about Investments, as you can see, " Life insurance provides savings, investment, and retirement income and it is bought not because people have to die, but because people have to go on living " got the highest weighted mean of 3.47 with the verbal interpretation of " with moderate knowledge" and " Investments are passive income " got the lowest weighted mean of 3.23 with a verbal interpretation of "with moderate knowledge". This implies that teachers will most likely invest in life insurance. When a person retires and is insured, family members may be responsible for large expenses such as funeral fees, as well as unforeseen medical and legal bills [16]. That is why it is important for a teacher to be insured.

\section{Major Reasons that Affect the Loan Decisions of Teachers \\ 2.1 Needs}

Table 4. Needs

\begin{tabular}{|ll|c|c|}
\hline \multicolumn{1}{|c|}{ Item } & WM & \multicolumn{1}{c|}{ VI } \\
\hline $\begin{array}{l}\text { 1. } \\
\text { My salary is not enough } \\
\text { and I'm the breadwinner } \\
\text { of the family. }\end{array}$ & 2.7 & $\begin{array}{l}\text { Probably won't } \\
\text { apply for a loan }\end{array}$ \\
\hline 2. & $\begin{array}{l}\text { My partner (husband or } \\
\text { wife) has no source of } \\
\text { income }\end{array}$ & 2.78 & $\begin{array}{l}\text { Probably won't } \\
\text { apply for a loan }\end{array}$ \\
\hline 3. & $\begin{array}{l}\text { Emergency needs (i.e., } \\
\text { medical expenses) }\end{array}$ & 2.67 & $\begin{array}{l}\text { Probably won't } \\
\text { apply for a loan }\end{array}$ \\
\hline 4. & $\begin{array}{l}\text { Allotment for children's } \\
\text { education }\end{array}$ & 2.81 & $\begin{array}{l}\text { Probably won't } \\
\text { apply for a loan }\end{array}$ \\
\hline
\end{tabular}




\begin{tabular}{|c|c|c|}
\hline $\begin{array}{c}\text { 5. } \\
\text { Education expenses } \\
\text { needed for possible } \\
\text { promotion }\end{array}$ & 2.68 & $\begin{array}{l}\text { Probably won't } \\
\text { apply for a loan }\end{array}$ \\
\hline General Weighted Mean & 2.728 & $\begin{array}{l}\text { Probably won't } \\
\text { apply for a loan }\end{array}$ \\
\hline
\end{tabular}

For the major reasons that affect the loan decisions of teachers in terms of their needs, "allotment for children's education" got the highest weighted mean of 2.81 with the verbal interpretation of "probably won't apply for a loan" and "emergency needs" got the lowest weighted mean of 2.67 verbally interpreted also as "probably won't apply for a loan". The findings show that teachers borrowed money due to emergency needs. It includes expenses due to unexpected or unforeseen events on the life of teachers such as personal or family emergencies, unwanted calamities, economic downturns, and other surprising happenings which need financial settlement. This means that teachers do not have or save emergency funds that they can utilize in an emergency or as a buffer to get out of the aforementioned situations. Teachers borrow money or take out loans for a variety of reasons, including health emergencies. The government's health insurance benefits are insufficient to satisfy the health needs of public-school teachers and their families, so they must rely on borrowed finances in the event of an emergency [17].

\subsection{Wants}

Table 5. Wants

\begin{tabular}{|c|c|c|}
\hline Item & $\mathbf{W M}$ & VI \\
\hline 1. Buy my dream house. & 2.55 & $\begin{array}{l}\text { Probably won't } \\
\text { apply for a loan }\end{array}$ \\
\hline 2. Purchase my own car. & 3.02 & $\begin{array}{l}\text { Probably won't } \\
\text { apply for a loan }\end{array}$ \\
\hline $\begin{array}{l}\text { 3. Additional capital for } \\
\text { business. }\end{array}$ & 2.61 & $\begin{array}{l}\text { Probably won't } \\
\text { apply for a loan }\end{array}$ \\
\hline 4. Traveling for leisure. & 3.35 & $\begin{array}{l}\text { Refuse to apply } \\
\text { for a loan }\end{array}$ \\
\hline $\begin{array}{l}\text { 5. Help my relatives who } \\
\text { are in need. }\end{array}$ & 2.86 & $\begin{array}{l}\text { Probably won't } \\
\text { apply for a loan }\end{array}$ \\
\hline General Weighted Mean & 2.878 & $\begin{array}{l}\text { Probably won't } \\
\text { apply for a loan }\end{array}$ \\
\hline
\end{tabular}

Table 5 shows that the lowest weighted mean got 2.55 (Buy my dream house) and the highest weighted mean is got 3.02 (Purchase of my own car).In short, in Table 5 result, the respondents' wants were not affected by their decision-making desires. Based on the overall weighted mean of 2.88 there's no possibility that respondents will choose to loan just because of their wants, respondents are known to be the lowest salary among the government employees, having insufficient funds. In terms of school assistants and personal needs. This survey confirms that respondents buying their own dream house being the lowest weighted mean, show that respondents don't prioritize because of no funds. Which "majority of our public-school teachers cannot afford to purchase their own homes at market prices since they earn gross monthly income of P10,000 or less" [18].

\section{CONCLUSIONS AND RECOMMENDATIONS}

The following conclusions were drawn based on the findings of this investigation. Teachers who have a better understanding of money management in terms of savings, spending, and investments can make more educated borrowing decisions. Teachers who lack the necessary abilities to manage savings, costs, and investments are more likely to take out large loans to satisfy their daily needs and wants, as well as to improve their welfare and level of living. Teachers' financial conduct will benefit from financial literacy instruction in terms of allotting for savings and investments after setting aside a well-planned budget for their necessities and costs. "Different financial literacy activities, such as seminars and training, will assist teachers in making wise financial decisions and ultimately achieve individual financial well-being and free to employ a solution of their own choice" [19]. Financial education should be included in higher education curricula to increase financial knowledge, behavior, and attitudes among young teachers [20] particularly in Cabanatuan City, Nueva Ecija[21] in order to help them live better lives.

\section{REFERENCES}

[1] Murphy, L. (2013), Psychosocial Factors and Financial Literacy, Social Security Bulletin, Vol. 73, No. 1, 2013. Retrieve from https://www.ssa.gov/policy/docs/ssb/v73n1/ v73n1p73.html

[2] Bhushan, P. (2014), Relationship Between Financial Literacy and Investment Behavior of Salaried Individuals, Journal of Business Management \& Social Sciences Research, 3(5), 2319-5614. Retrieved from http://www.borjournals.com/a/index.php/jbmssr/article/ view/1707/1066

[3] Capuano, A. \& Ramsay, I. (2011), What Causes Suboptimal Financial Behaviour? An Exploration of Financial Literacy, Social Influences and Behavioural 
Economics, Melbourne Legal Studies Research Paper, doi:10.2139/ssrn.1793502

[4] Oksanen, Aaltonen and Rantala (2015), Social Determinants of Debt Problems in a Nordic Welfare State: a Finnish Register-Based Study, Journal of Consumer Policy, Vol. 38, Issue 3, 229-246. Retrieve from https://econpapers.repec.org/article

[5] Asian Development Bank (2015), Financial Education in Asia: Assessment and Recommendations, ADBI Working Paper Series No. 534. Retrieve from https://www.adb.org > publication > adbiwp534

[6] Amelina, ApriciaSjam (2015), Financial Literacy of College Students: Determinants and Implications. Retrieve from https://media.neliti.com/media/publications/115171EN-financial-literacy-of-college-students-d.pdf

[7] Manulife Financial Corporation (2016), Filipinos Good Short-Term Savers, but Rank High in Debt-Poll, Rappler. Retrieved from https://www.rappler.com/business/industries/209-bankingandfinancial-services/124948-filipinosdebt-asia-manulifesurvey

[8] Hastings, J.S. \& Mitchell, O. S. (2011), How Financial Literacy and Impatience Shape Retirement Wealth and Investment Behaviors, National Bureau of Economic Research,Working Paper, WP 16740. Retrieved from http://www.nber.org/papers/w16740

[9] Lopez, M. L. (2016), Many Filipinos Found to Be Still Dependent on Debt, Business World Online. Retrieved from www.bworldonline.com

[10] Jappelli, T. \&Padula, M. (2013), Investment in Financial Literacy and Saving Decisions, Journal of Baking and Finance, 37(8), 2779-2792. doi:10.1016/ j.jbankfin.2013.03.019

[11] World Bank (2015), Enhancing Financial Capability and Inclusion in the Philippines - A Demand-side Assessment. Retrieved from http://responsiblefinance.worldbank.org/ / media/GIAWB/FL/Documents/Publications/EnhancingFinancial-Capability-and-Inclusion-in-the-PhilippinesFINAL.pdf

[12] Montalbo, Pogoy, Villarante\&Pepito (2017), Financial Literacy of Professional and Pre-Service Teachers in the Philippines, Research Article, Journal of Global Economics, ISSN: 2375-4389. Retrieve from https://www.researchgate.net/publication/322375634

[13] Aggarwal, Y.P. (2008). Statistics of Education. (2nd Ed.) Delhi: Sterling

[14] Dhawan, S. (2018), Financial Planning Thumb Rules, Retrieved from https://economictimes.indiatimes.com/wealth/plan/financial -planning-thumb-rules/articleshow/54439162.cms

[15] Gravier, E. (2021), 3 Easy Ways You Can Track Your Expenses and Stay on Top of Your Money.URL: https://www.cnbc.com/select/how-to-trackexpenses

[16] https://www.ctamemberbenefits.org/beprotected

[17] Ferrer, J. (2017), Caught in a Debt Trap? An Analysis of the Financial Well-being of Teachers in the Philippines, Research Article, The Normal Lights, Volume 11, No. 2.
Retrieve from https://www.researchgate.net/publication/ $\underline{321996577}$

https://depedclub.com/providing-a-housing-program-forteachers-pushed/

[18] Salangsang, L., \& Subia, G. (2020). Mathematical thinking on problem-solving and self-regulation strategies of Filipino primary grade pupils. International Journal of Scientific \& Technology Research, 9(2). ISSN 2277-8616.

[19] Subia, G., Salangsang, L. and Medrano, H. (2018) Attitude and Performance in Mathematics of Bachelor of Elementary Education Students: A Correlational Analysis. American Scientific Research Journal for Engineering, Technology, and Sciences (ASRJETS), 39, 206-213.

[20] Mina, J.C., Barlis, P.T., Vega, N.C. and Subia, G.S. (2019). Corporate Social Responsibilities of Selected Resorts in Cabanatuan City, Nueva Ecija, Philippines. Open Access Library Journal, 6: $\quad$ e 5292. https://doi.org/10.4236/oalib.1105292. 